\title{
Singer $v$. United States and the Misapprehended Source of the Nonconsensual Bench Trial
}

An issue that frequently arises in criminal prosecutions is whether special procedural measures are required to protect a defendant from the possibility of a partial jury. ${ }^{1}$ One such measure, though not often considered as such, ${ }^{2}$ is to allow the defendant to waive his right to a jury and submit to a bench trial..$^{3}$ Federal Rule of Criminal Procedure 23(a), however, permits a defendant to waive trial by jury only with "the approval of the court and the consent of the government," thereby significantly curtailing the availability of a bench trial as a means of countering jury partiality in federal criminal proceedings. The constitutionality of the rule's requirement of government consent was upheld in Singer $v$. United States. ${ }^{B}$ Singer also raised the possibility that government consent might not be required where "the Government's insistence on trial by jury would result in the denial to a defendant of an impartial trial."

This comment argues that the possibility raised by Singer-that the defendant's right to an "impartial trial" may enable the defendant to insist on a bench trial-is wholly illusory. After establishing that the Singer caveat can only conceivably rest upon the defendant's due process right to a fair trial, the comment surveys the current case law interpreting Singer and finds that it largely fails to explain when this right entitles the defendant to a

1 For a discussion of a number of potential sources of jury prejudice, see infra notes 3641 and accompanying text. This comment uses "prejudice" interchangeably with "partiality."

3 See, e.g., Sheppard v. Maxwell, 384 U.S. 333, 363 (1966) (failing to mention a bench trial as among the possible protections against partiality). For a discussion of the traditional procedural mechanisms for guarding against prejudice, see infra notes 56-61 and accompanying text.

s A defendant may want a bench trial for reasons other than avoiding the possibility of prejudice. For example, a defendant may simply desire to save time by foregoing a jury trial. See, e.g., Singer v. United States, 380 U.S. 24, 25 (1965).

- FED. R. CRIM. P. 23(a) in its entirety provides: "Trial by jury. Cases required to be tried by jury shall be so tried unless the defendant waives a jury trial in writing with the approval of the court and the consent of the government."

5 380 U.S. 24 (1965).

- Id. at 37 . 
nonconsensual bench trial. The comment then argues that the defendant has no right to a bench trial under the fair trial guarantee until he demonstrates that it is impossible for him to receive an impartial jury trial. However, since a defendant has an absolute right to a trial by an impartial jury, any defendant who makes such a demonstration is entitled to a dismissal, thereby rendering any right to a bench trial grounded in the fair trial guarantee superfluous.

Despite the conclusion that the fair trial guarantee never meaningfully requires a nonconsensual bench trial, the comment maintains that other constitutional provisions provide a basis for overriding the government's interest in trial by jury whenever the defendant is entitled to an impartial jury safeguard ${ }^{7}$ that itself infringes these protected constitutional interests. Finally, the comment examines the policy bases of the consent requirement, and argues that they are too insubstantial to justify conditioning the availability of a nonconsensual bench trial upon the exhaustion of any alternative impartial jury safeguard. The comment concludes that Rule 23(a) should be amended to permit the defendant to insist upon a bench trial once he has demonstrated jury partiality.

\section{BACKGROUND}

The United States Constitution provides both in article III and in the sixth amendment ${ }^{9}$ for trial by jury in criminal cases. These provisions were traditionally construed to prohibit a federal criminal defendant from waiving a jury trial. ${ }^{10}$ In Patton $v$. United

7 See infra notes 56-61 and accompanying text.

- U.S. CoNST. art. III, § 2, cl. 3 provides, in part, that the "Trial of all Crimes, except in Cases of Impeachment, shall be by Jury." This provision applies only to trials in federal courts, Eilenbecker v. District Court, 134 U.S. 31, 35 (1890), and does not extend to petty offenses, Schick v. United States, 195 U.S. 65, 70 (1904); Callan v. Wilson, 127 U.S. 540, 555 (1888).

- U.S. ConST. amend. VI provides, in part, that "[i]n all criminal prosecutions, the accused shall enjoy the right to a speedy and public trial, by an impartial jury . . . ." Like article III, this provision applies only to federal proceedings. Eilenbecker v. District Court, 134 U.S. 31, 34 (1890). However, various elements of this provision have been applied against the states by incorporation into the due process clause of the fourteenth amendment. See Duncan v. Louisiana, 391 U.S. 145 (1968) (trial by jury); Klopfer v. North Carolina, 386 U.S. 213 (1967) (speedy trial); In re Oliver, 333 U.S. 257 (1948) (public trial).

${ }^{10}$ See, e.g., Schick v. United States, 195 U.S. 65, $81-82$ (1904) (Harlan, J., dissenting); Frank v. United States, 192 F. 864, 867-68 (6th Cir. 1911); Low v. United States, 169 F. 86, 90-92 (6th Cir. 1909); Dickinson v. United States, 159 F. 801, 811 (1st Cir. 1908), cert. dismissed, 213 U.S. 92 (1909); United States v. Gilbert, 25 F. Cas. 1287, 1306 (C.C.D. Mass. 1834) (No. 15,204). 
States, ${ }^{11}$ however, the Supreme Court decided that trial by jury is not a jurisdictional requirement but a "privilege" of the accused, which "he may forego at his election."12 Patton- emphasized that trial by jury, though not constitutionally required in the face of a defendant's waiver, is nonetheless the "preferable mode" of resolving issues of fact in felony prosecutions and that its "value and appropriateness" has been "established by long experience."13 In dictum, the Court went on to state that the jury "has such a place in our traditions, that before any waiver can become effective, the consent of government counsel and the sanction of the court must be had, in addition to the express and intelligent consent of the defendant."14

Federal Rule of Criminal Procedure 23(a), promulgated by the Supreme Court a decade later, codified both the holding and the dictum of Patton. ${ }^{15}$ Despite its grounding in the Supreme Court's language, the constitutionality of the rule was nevertheless challenged in Singer $v$. United States. ${ }^{16}$

\section{A. Singer: The Nonconsensual Bench Trial as a Requirement of the Fair Trial Guarantee}

In Singer, the defendant sought to shorten his trial by waiving his right to a jury; the government refused to consent. ${ }^{17}$ Based on an examination of English common law, colonial law, the records of the federal convention, and the case law, including Patton, the Court rejected Singer's argument that he had a constitutional right to a bench trial. ${ }^{18}$ In addition, Chief Justice Warren denied Singer's further claim that forcing a defendant to undergo a jury

11281 U.S. 276 (1930).

12 Id. at 298.

13 Id. at 312.

14 Id.

${ }^{16}$ FED. R. CRIM. P. 23(a) advisory committee note 2. Rule 23 is among the federal rules of criminal procedure promulgated by the Supreme Court pursuant to its authority granted by the Act of June 29, 1940, Pub. L. No. 76-675, 54 Stat. 688 (codified as amended at 18 U.S.C. $\$ 3771$ (1982)). Rules reported to Congress at the beginning of a regular session take effect no later than 90 days thereafter. Id.

18 380 U.S. 24 (1965). Inquiry into the validity of a federal rule of criminal procedure is not foreclosed by the fact that the Supreme Court has adopted the rule. See United States v. Bink, 74 F. Supp. 603, 615 (D. Or. 1947).

17380 U.S. at 25.

18 Id. at 27-34. For an investigation of the early history of waiver of jury trial in criminal cases, see Griswold, The Historical Development of Waiver of Jury Trial in Criminal Cases, 20 VA. L. REv. 655 (1934); Oppenheim, Waiver of Trial by Jury in Criminal Cases, 25 Mich. L. Rev. 695 (1927); Towne, The Historical Origins of Bench Trial for Serious Crime, 26 Am. J. Legal Hist. 123 (1982). 
trial against his will is contrary to his "right to a fair trial or to due process." A defendant's "only constitutional right concerning the method of trial," the Court stated, "is to an impartial trial by jury."20 Therefore, there exists "no constitutional impediment" to the requirement of government consent in Rule 23(a), since the result of the government's refusal to consent "is simply that the defendant is subject to an impartial trial by jury-the very thing that the Constitution guarantees him."21 As a corollary, where the government's refusal to consent would preclude an "impartial trial by jury," the requirement of consent would seem to face a constitutional impediment; the Court, however, in the central passage of the opinion, reserved the question:

We need not determine in this case whether there might be some circumstances where a defendant's reasons for wanting to be tried by a judge alone are so compelling that the Government's insistence on trial by jury would result in the denial to a defendant of an impartial trial ... . [though] [p]etitioner argues that there might arise situations where "passion, prejudice, ... public feeling" or some other factor may render impossible or unlikely an impartial trial by jury. ${ }^{22}$

This was not such a case, the Court concluded, because Singer gave "no reason for wanting to forgo [sic] jury trial other than to save time."23

The Court's description of the constitutional right upon which this passage centers-the right to an "impartial trial by jury"-is ambiguous. A number of commentators, perhaps misled by the

38 U.S. at 36.

20 Id.

21 Id. at 36. Because of its confidence in the integrity of the federal prosecutor, the Court also ruled that Rule 23(a) does not require the government to articulate its reasons for refusing to consent to a bench trial. Yet the Court hinted that were the prosecutor to demand a jury trial for "an ignoble purpose," the consent requirement might be suspended. Id. at 37. For lower courts' treatment of this issue, see United States v. Braunstein, $474 \mathrm{~F}$. Supp. 1, 14 (D.N.J. 1979) (defendant who shows overwhelmingly sound reasons for a nonjury trial may prevail when government fails to reveal the standards by which its consent is withheld); United States v. Panteleakis, 422 F. Supp. 247, 250 (D.R.I. 1976) (government's refusal to consent arbitrary and unreasonable); United States v. Mayr, 350 F. Supp. 1291, 1294 (S.D. Fla. 1972) (in the absence of allegations of evidence of bad faith, government may refuse consent to waiver of jury despite complex subject matter), aff'd, 487 F.2d 67 (5th Cir.), cert. denied, 417 U.S. 914 (1974); United States v. Schipani, 44 F.R.D. 461, 463 (E.D.N.Y. 1968) (government's refusal to consent to a nonjury trial unreasonable in view of danger of prejudice); United States v. Daniels, 282 F. Supp. 360, 361 (N.D. Ill. 1968) (no suggestion that government's purpose is "ignoble").

22380 U.S. at $37-38$ (quoting Brief for Petitioner at 24).

23380 U.S. at 38. 
words "impartial" and "jury," have understood the possibility of a right to a bench trial raised by Singer to derive from the defendant's sixth amendment right to an "impartial jury." that the government's refusal to consent could indeed foist a partial jury upon the defendant. Nonetheless, the fact that a defendant has a right to an impartial jury does not logically entail a right to waive a jury trial and insist on a bench trial, since neither waiving a jury trial nor obtaining a bench trial would preserve the defendant's right to an impartial jury. ${ }^{25}$

The source of confusion lies in Singer's failure to distinguish carefully the defendant's sixth amendment right to an "impartial jury" ${ }^{\prime 26}$ from the defendant's due process right to a fair and impartial trial. ${ }^{27}$ As just noted, the Singer caveat is incoherent when construed to refer to the former right: a bench trial can not preserve the impartial jury guarantee and therefore that guarantee cannot provide a source for a right to a bench trial. ${ }^{28}$ By contrast, where a jury is insufficiently impartial, the due process clause's guarantee

24 Donnelly, The Defendant's Right to Waive Jury Trial in Criminal Cases, 9 U. FLA. L. Rev. 247, 254 (1956); Comment, Waiving the Right to a Jury Trial in the Federal Courts: The Burden of Prejudice, 7 Surpolk U.L. REv. 973, 982 (1983) [hereinafter cited as Comment, Burden of Prejudice]; Comment, The Government's Interest as a Party Litigant in Federal Criminal Proceedings, 26 U. PrTT. L. REv. 767, 772 (1965) [hereinafter cited as Comment, The Government's Interest]; Note, Government Consent to Waiver of Jury Trial Under Rule 23(a) of the Federal Rules of Criminal Procedure, 65 YALE L.J. 1032, 1035, 1038 (1956) [hereinafter cited as Note, Government Consent]. But see Note, Waiver of Trial by Jury Following Waiver of Counsel, 25 CATH. U. L. REV. 380, 389 (1976) (issue posed by Singer is whether the requirement of government consent might violate the due process clause of the fifth amendment by denying the defendant a fair trial) (hereinafter cited as Note, Waiver Following Waiver of Counsel]; Comment, Waiver of Jury Trials in Federal Criminal Cases: A Reassessment of the "Prosecutorial Veto," 51 Fordham L. REv. 1091, 1091 n.1, 1106 (1983) (same) [hereinafter cited as Comment, Waiver of Jury Trials].

${ }^{25}$ Nor does any plausible construction of the impartial jury guarantee suggest otherwise. See infra notes 86-94 and accompanying text.

26 U.S. Const. amend. VI. Article III of the Constitution also provides that the "Trial of all Crimes, except in cases of Impeachment, shall be by Jury." U.S. CoNST. art. III, § 2, cl. 3.

${ }^{27}$ See, e.g., United States v. Agurs, 427 U.S. 97, 107 (1976) (defendant is guaranteed a fair trial by the due process clause of the fifth amendment); In re Murchison, 349 U.S. 133, 136 (1955) ("[F]air trial in a fair tribunal is a basic requirement of due process."). The due process clause of the fourteenth amendment also guarantees "the fundamental elements of fairness in a criminal trial." Spencer v. Texas, 385 U.S. 554, 563-64 (1967); Betts v. Brady, 316 U.S. 455, 465, 473 (1942), overruled, Gideon v. Wainwright, 372 U.S. 335 (1963). But cf. Nebraska Press Ass'n v. Stuart, 427 U.S 539, 596, (1976) (Brennan, J., concurring) (fair trial guarantee treated as springing from the sixth amendment).

23 This argument presupposes that the impartial jury guarantee confers a positive entitlement to an impartial jury upon the defendant and is not merely a means to ensuring a fair trial. See infra notes $86-94$ and accompanying text. 
of a fair trial may be preserved by and therefore require a bench trial. ${ }^{29}$

Because a "fair trial" requires an "impartial" tribunal, ${ }^{30}$ the Court's reference to an "impartial trial"s1 is not inexplicable. Nonetheless, the source of the putative right to a bench trial identified in Singer, as the briefs of the parties in Singer ${ }^{32}$ and the following examination of the post-Singer case law confirm, ${ }^{33}$ is not the sixth amendment jury guarantee but the due process guarantee of a fair trial.

\section{B. Singer's Progeny}

Lower courts confronted with the issue of a nonconsensual bench trial have invariably fastened upon the "passion, prejudice[, or] public feeling" language of Singer and have apparently assumed that once the defendant establishes jury prejudice he is entitled to a nonconsensual bench trial. ${ }^{34}$ Typically, the cases have failed to analyze the actual issue raised by Singer, namely, whether the government's insistence on a jury trial denies the defendant a

20 This argument assumes, of course, that a bench trial would not also be a partial trial and thus would indeed preserve the defendant's right to a fair trial.

so In re Murchison, 349 U.S. 133, 136 (1955); see also Duncan v. Louisiana, 391 U.S. 145, 179 (1968) (Harlan, J., dissenting) ("fairness demands a jury impartially selected"); Wong Yong Sung v. McGrath, 339 U.S. 33, 50 (1950) (any hearing required by the Constitution must meet "at least currently prevailing standards of impartiality").

31 Singer, 380 U.S. at 37.

3* Brief for Petitioner at 7, 24-25, 27, Singer v. United States, 380 U.S. 24 (1965); Brief for the United States in Opposition to Writ of Certiorari at 6, Singer v. United States, 380 U.S. 24 (1965); see also Motion of Joni Rabinowitz for Leave to File Brief Amicus Curiae and Brief at 16-17, Singer v. United States, 380 U.S. 24 (1964).

ss See infra notes 40, 43-55 and accompanying text.

34 See, e.g., United States v. Alpern, 564 F.2d 755, 758 (7th Cir. 1977) (suggesting that if the jury was so inflamed by passion and prejudice as to be unable to separate the guilty from the innocent, defendant would be entitled to a nonconsensual bench trial); United States v. Wright, 491 F.2d 942, 945 (6th Cir.) (suggesting that if publicity has been prejudicial enough to deny the defendant an impartial trial, the trial judge may allow a waiver of jury trial over the government's objection), cert. denied, 419 U.S. 862 (1974); United States v. Kramer, 355 F.2d 891, 899 (7th Cir.) (implying that the jury's having been so inflamed as to be prevented from making a fair assessment of the evidence would have been compelling reason for rejecting the government's insistence on trial by jury), cert. granted in part, denied in part, 384 U.S. 100 (1966); United States v. Panteleakis, 422 F. Supp. 247, 250 (D.R.I. 1976) (where evidentiary issues render substantial prejudice practically impossible to avoid, nonconsensual bench trial granted); see also United States v. Sun Myung Moon, 718 F.2d at 1210, 1218-19 (2d Cir. 1983) (upholding denial of bench trial where trial court found that jury was unbiased), cert. denied, 52 U.S.L.W. 3828 (U.S. May 15, 1984); United States v. Stone, 444 F. Supp. 1254, 1257 (E.D. Wis.) (where counsel's argument and court's instruction can avert the danger of jury confusion, nonconsensual bench trial denied), aff'd, 588 F.2d 834 (7th Cir. 1978). 
fair trial. What dominates the case law instead is whether the defendant successfully demonstrated jury partiality. ${ }^{35}$

Of the twenty or so cases that have considered the nonconsensual bench trial issue since Singer, the great majority have ruled that the defendant failed to establish jury partiality, whether claims of partiality rested on the complexity of the case, ${ }^{36}$ the disclosure of the defendant's criminal record, ${ }^{37}$ religious prejudice, ${ }^{38}$ racial prejudice,,$^{39}$ pre-trial publicity, ${ }^{40}$ or the admission of evidence

ss Not all the jury-waiver cases decided subsequent to Singer have purported to address the Singer issue. At least one court assumed without deciding that Singer established a conditional right to a bench trial but found Singer inapplicable to the facts of the case. United States v. Ceja, 451 F.2d 399, 401 (1st Cir. 1971). Two other cases simply ignored the question raised by Singer. United States v. Bowles, 428 F.2d 592, 594-95 (2d Cir.), cert. denied, 400 U.S. 928 (1970); United States v. Barber, 297 F. Supp. 917, 923 (D. Del. 1969).

se See United States v. Sun Myung Moon, 718 F.2d 1210, 1218 n.1 (2d Cir. 1983) (taxfraud prosecution with hundreds of exhibits), cert. denied, 52 U.S.L.W. 3828 (U. S. May 15, 1984); United States v. Houghton, 554 F.2d 1219, 1226 (1st Cir.) (claim that jury would not understand informant situation), cert. denied, 434 U.S. 851 (1977); United States v. Caldarazzo, 444 F.2d 1046, 1050 (7th Cir. 1971) (factual complexities in conspiracy charge), cert. denied, 404 U.S. 958 (1974); United States v. Simon, 425 F.2d 796, 799 n.1 (2d Cir. 1969) (complexity of subject matter of alleged offense), cert. denied, 397 U.S. 1006 (1970); United States v. Mayr, 350 F. Supp. 1291, 1294 (S.D. Fla. 1972) (same), aff'd, 487 F.2d 67 (5th Cir. 1974). As one of these courts suggested, allegations of complexity bear no relation to a "claim of partiality as to the jurors." Houghton, 554 F.2d at 1226.

s7 In two instances, defendants who feared that taking the stand would reveal their criminal records were denied a bench trial. In United States v. Kramer, 355 F.2d 891, 899 (7th Cir.), cert. granted in part, denied in part, 384 U.S. 100 (1966), the court ruled that "hypothetical prejudice does not give rise to the exceptional situation which might render impartial trial by jury unlikely or impossible . . . ." The other court refused to rule that a jury trial would be "inherently unfair or that it would impair defendant's right to have the fair and impartial trial to which he is entitled." United States v. Harris, 314 F. Supp. 437, 439 (D. Minn. 1970). But cf. United States v. Schipani, 44 F.R.D. 461 (E.D.N.Y. 1968) (potential disclosure of criminal record sufficient to bar jury trial where government had previously agreed to jury waiver but later sought to withdraw consent).

s8 In United States v. Sun Myung Moon, 718 F.2d 1210, 1218 (2d Cir. 1983), cert. denied, 52 U.S.L.W. 3828 (U.S. May 15, 1984), the Reverend Sun Myung Moon claimed that animosity towards his religion would prevent him from receiving a fair trial on tax fraud charges. The Second Circuit agreed with the trial court's finding that the jury was sufficiently impartial to render Moon a fair trial. Id. at 1218-1219.

so In United States v. Ceja, 451 F.2d 399 (1st Cir. 1971), the defendant, a Cuban convicted before the United States District Court for the District of Puerto Rico, claimed that racial prejudice against Cubans prevented a fair trial by jury. In rejecting this argument, the First Circuit held that the challenger's burden of demonstrating the partiality of jurors could be met only by showing, through voir dire, "'the actual existence of such an opinion in the mind of the juror as will raise the presumption of partiality.' "Id. at 401 (quoting Reynolds v. United States, 98 U.S. 145, 157 (1878)). The court ruled that this burden was not met, and that therefore there was no showing of partiality that would prevent the defendant from receiving a fair trial.

10 Four different circuits have refused to overturn trial court denials of defendant requests for a bench trial based on adverse pre-trial publicity. In United States v. Wright, 491 F.2d 942, 945 (6th Cir.), cert. denied, 419 U.S. 862 (1974), the court held that the publicity 
properly admissible only against co-defendants in multiple-defendant cases." Although these cases have not always agreed on the proper test for establishing partiality, ${ }^{42}$ together they suggest that

was not "per se . . . so prejudicial as to deny the appellants an impartial trial." In United States v. Morlang, 531 F.2d 183, 187 (4th Cir. 1975), the Fourth Circuit emphasized that where no evidence was offered to establish "actual prejudice on the part of any of the prospective jurors" and the record indicated "no substantial likelihood that any of the prospective jurors would have been unfair or biased in rendering their verdict," there was an insuffcient basis from which to conclude that the use of a jury would substantially diminish the probability of a fair trial. The court suggested that were a bench trial to "increase the likelihood of a fair trial," the requirements of Singer might be satisfied. Id. at 187 \& n.10. In United States v. Farries, 459 F.2d 1057 (3d Cir. 1972), cert. denied, 409 U.S. 888 (1972), and cert. denied, 410 U.S. 912 (1973), the court considered whether a Black Muslim charged with participating in a prison mutiny and riot was entitled to a nonconsensual bench trial. Despite pretrial publicity, alleged prejudice against Black Muslims, and the contention that the jury would inevitably know from the nature of the charges that the defendant was a convicted felon, the court held that the denial of a bench trial was proper. Id. at 1060-61. In dictum, the court conceded that the case might have been decided differently had there been a "substantial likelihood that pre-trial publicity had tainted the jury panel." Id. at 1061. Finally, in Thwing v. South Dakota, 470 F.2d 351, 353 (8th Cir. 1972), cert. denied, 411 U.S. 973 (1973), the Eighth Circuit denied the defendant's motion for a bench trial because he failed to establish that publicity engendered "actual prejudice." Thwing is notable for containing one of the rare passages in the post-Singer case law in which any analysis of the question posed by Singer may be discerned. The court acknowledged that when pretrial publicity is so prejudicial that a fair and impartial trial is impossible, due process requires the judge to "take some corrective steps to ensure the accused a fair trial." Id. at 353. The court added, however, that "nothing about a request for a non-jury trial . . . converts the due process clause from a general guaranty of a fair trial into a specific guaranty of a non-jury trial." Id. The Thwing court, however, did not follow through on this insight, and indeed, may have abandoned it in subsequently framing the "fundamental issue" as whether the publicity "deprived the accused of a fair and impartial trial." Id. The passage is nevertheless suggestive of the analysis required by Singer. See infra notes 56-68 and accompanying text. The only other case that even begins to analyze the Singer issue is United States v. Daniels, 282 F. Supp. 360 (N.D. Ill. 1968), discussed infra at notes 52-55 and accompanying text.

41 In United States v. Stone, 444 F. Supp. 1254, 1257 (E.D. Wis.), aff'd, 588 F.2d 834 (7th Cir. 1978), the court refused to hold that the admission of such evidence meant that the defendant could not "receive an impartial jury trial." Similarly, the Seventh Circuit declined to conclude that evidentiary problems in a multiple defendant case rendered the jury "unable to separate the guilty from the innocent." United States v. Alpern, 564 F.2d 755, 758 (7th Cir. 1977). But see United States v. Braunstein, 474 F. Supp. 1, 14 (D.N.J. 1979) (finding "heavy risk" that, with five separate defendants, the jury might hold against one defendant evidence admissible only as to another); United States v. Panteleakis, $422 \mathrm{~F}$. Supp. 247, 250 (D.R.I. 1976) (finding it "unrealistic" to expect a jury to categorize evidence pertaining to each particular defendant in a complex multiple defendant trial). Both cases are discussed infra notes $43-46$ and accompanying text.

12 The cases disagree as to the degree of certainty with which prejudice must be established. On the one hand, some of the cases suggest that a categorical showing is necessary. See, e.g., , United States v. Alpern, 564 F.2d 755, 758 (7th Cir. 1977) (bench trial denied where jury not "unable" to separate guilty from innocent); Thwing v. South Dakota, 470 F.2d 351, 353 (8th Cir. 1972) (actual prejudice); United States v. Kramer, 355 F.2d 891, 899 (7th Cir.) (hypothetical prejudice insufficient to compel grant of waiver), cert. granted in part, denied in part, 384 U.S. 100 (1966); United States v. Stone, 444 F. Supp. 1254, 1257 
partiality is not readily established.

Four cases, however, ruled that the defendant did establish partiality. In United States $v$. Panteleakis, ${ }^{43}$ the court noted that the difficulty a jury would have in segregating the evidence presented in a multiple-defendant trial made "substantial prejudice . . . practically impossible to avoid," and ruled that the court's duty to protect the defendant's right to a "fair trial" compelled it to grant a bench trial. ${ }^{44}$ In United States $v$. Braunstein, ${ }^{45}$ where similar evidentiary problems created an "extremely high and compelling" risk of prejudice to a "fair trial" and made it "most unlikely" that the jury could properly segregate the evidence, a nonconsensual bench trial was again granted. ${ }^{46}$

In United States v. Schipani,"7 the defendant was charged with income-tax evasion; the prosecution's case rested on a "net worth theory" that required "all facets of the defendant's financial history ... to be fully explored."48 The district court observed

(E.D. Wis.) (bench trial denied where judge unable to find that defendant "cannot" receive impartial jury), aff'd, 588 F.2d 834 (7th Cir. 1978). On the other hand, a number of cases suggest that a lesser showing will suffice. See, e.g., United States v. Farries, 459 F.2d 1057, 1061 (3d Cir. 1972) ("substantial likelihood" of prejudice); United States v. Braunstein, 474 F. Supp. 1, 14 (D.N.J. 1979) ("extremely high and compelling risk" of prejudice); United States v. Panteleakis, 422 F. Supp. 247, 250 (D.R.I. 1976) ("substantial prejudice . . . practically impossible to avoid"). One case wavers between these divergent views. See United States v. Morlang, 531 F.2d 183, 187 (4th Cir. 1975) (suggesting that actual prejudice is required, but then referring to substantial likelihood of prejudice). These differing standards in the post-Singer case law derive from the dual "impossible or unlikely" standard suggested by Singer itself. 380 U.S. at 37-38.

This disagreement over the certainty of prejudice that must be established parallels a tension in the general case law on partiality. Compare Reynolds v. United States, 98 U.S. 145, 157 (1878) (defendant must show "the actual existence of such an opinion in the mind of the juror as will raise the presumption of partiality"), with Sheppard v. Maxwell, 384 U.S. 333,363 (1966) (where there is a "reasonable likelihood" that prejudicial publicity will prevent a fair trial, judge may continue the case, transfer it to another county, or sequester the jury).

4s 422 F. Supp. 247 (D.R.I. 1976).

4 Id. at 250.

4544 F. Supp. 1 (D.N.J. 1979).

48 Id. at 14. The Braunstein court asserted that its ruling was not based on constitutional grounds-as the question reserved in Singer was-but on "a reading of Rule 23(a) together with Rule 2" of the Federal Rules of Criminal Procedure. Id. Rule 2 provides, in part, that the Federal Rules of Criminal Procedure shall be construed to secure "the elimination of unjustifiable expense and delay." FED. R. CRIM. P. 2. The court also suggested that since a jury trial would have taken substantially longer than a bench trial, insistence on a jury trial would impair the court's affirmative obligation to "conduct each trial as efficiently and expeditiously as possible" lest the rights of other defendants under the Speedy Trial Act, 18 U.S.C. $\S \S 3161-3174$ (1982), be adversely affected. Braunstein, 474 F. Supp. at 14.

47 F.R.D. 461 (E.D.N.Y. 1968).

${ }^{43} I d$. at 463. 
that a jury would be "immediately apprised" of the defendant's prior criminal record, would be likely to "link [him] with organized crime," and might "weigh this against him in determining guilt."49 The court further noted that "derogatory information" unearthed at a well-attended suppression hearing might be conveyed inadvertently to jury members. ${ }^{50}$ The court therefore denied the government's motion to withdraw its consent to a non-jury trial..$^{51}$

Finally, in United States $v$. Daniels, ${ }^{52}$ the United States District Court for the Northern District of Illinois acknowledged its responsibility to mitigate the prejudicial effect of "massive" pretrial publicity, ${ }^{53}$ but held that the defendants were not entitled to a bench trial. The court interpreted Singer as conditioning a nonconsensual bench trial on a showing that "the publicity carried so much prejudice as to make it incumbent on this court to grant defendants' motion, on the ground that only in this manner can the defendants' right to a fair and impartial trial be preserved." suggesting that a number of ameliorative procedures were available, it ruled that a continuance was required by the facts of the case, since "there is the possibility that a fair and impartial jury might be chosen in this district even now."

of the four cases that have found prejudice and so reached the question raised by Singer as to the defendant's right to a nonconsensual bench trial, only Daniels recognized that a showing of prejudice alone does not bring that right into play. Yet even the Daniels court failed to elucidate either the basis or the consequences of its insight that only upon the exhaustion of alternative devices for preventing jury prejudice does the fair trial guarantee require that a defendant have a right to a nonconsensual bench trial. After demonstrating the correctness of the Daniels court's insight, this comment will show that its consequences are striking: a

\footnotetext{
"Id.

so Id. at 464. withdrawal of consent).

- ${ }^{32} 282$ F. Supp. 360 (N.D. Ill. 1968).

ss Id. at 361 .

st Id. (emphasis added).

ss Id.
}

s1 The government had initially consented to a waiver, but sought to withdraw that consent when the conviction was vacated and a new trial ordered. As the first ground for its holding, the court determined that since the new trial was pursuant to the original indictment, the government's consent was not limited to the first trial. Id. at 462 . Schipani's treatment of the Singer issue is at best an alternative holding and has been treated as mere dictum. United States v. Harris, 314 F. Supp. 437, 438 (D. Minn. 1970). But see United States v. Panteleakis, 422 F. Supp. 247, 249 (D.R.I. 1976) (Schipani "holding" not limited to 
defendant who shows that a bench trial is the only way to secure a fair trial is entitled to dismissal, thereby rendering any right to a nonconsensual bench trial grounded in the fair trial guarantee meaningless.

\section{The Irrelevance of the Defendant's Fair Trial GuaranteE}

This section demonstrates that the reasoning in Daniels, when carried to its logical conclusion, does not lead to a meaningful right to a nonconsensual bench trial based on the fair trial guarantee. There are four steps to the argument. First, the defendant's right to a fair trial entitles him to a nonconsensual bench trial only as a remedy of last resort; the defendant who seeks a bench trial over the government's objection based on the fair trial guarantee must establish not only jury partiality but the inefficacy of every other procedure designed to remedy such partiality. Second, having thus established the inevitability of receiving a partial jury, the defendant has necessarily demonstrated a violation of his sixth amendment right to an impartial jury. Third, such a violation entitles the defendant to have his case dismissed since, having a right to an impartial jury, the defendant may not be convicted except by such a jury, unless he waived his right to it. Fourth, dismissal cannot be avoided by maintaining that the defendant has waived his impartial jury guarantee by requesting a bench trial. These arguments are considered in turn.

\section{A. The Last-Resort Argument}

Forcing the defendant to submit to a jury trial does not violate his due process right to a fair trial unless he is thereby tried by a partial jury. A defendant who has demonstrated the partiality of the present jury or even the partiality of all juries drawn from the immediate venire has not thereby established that he is doomed to a trial by a partial jury since he may still request a variety of measures designed to cure such partiality. These procedures are at once remedial and prophylactic-i.e., they are responsive to a successful demonstration of the possibility of prejudice, yet prevent a partial jury trial from ever occuring. They include continuance, ${ }^{56}$

Es This remedy is recognized both statutorily, 18 U.S.C. $\S 3161(h)(8)$ (1982), and in the case law, see, e.g., Sheppard v. Maxwell, 394 U.S. 333, 363 (1966) (continuance should be granted when prejudicial publicity presents a "reasonable likelihood of an unfair trial"). As Sheppard suggests and as the lower courts have held, the defendant may not demand a 
jury sequestration, ${ }^{57}$ change of venue, ${ }^{58}$ severance of trials in which defendants are joined, ${ }^{58}$ closure, ${ }^{60}$ and prior restraining orders restricting press coverage ("gag order"). ${ }^{61}$ Before the fair trial guarantee entitles a defendant to a bench trial, he must not only establish partiality-as emphasized in the post-Singer case law-but must further demonstrate that these procedures cannot cure such partiality. Without this second showing the defendant cannot claim, in the language of Singer, that a denial of an impartial trial

continuance until he has adequately shown prejudice. See, e.g., United States v. Hall, 536 F.2d 313, 326 (10th Cir.) (prejudicial publicity not such as to call for continuance), cert. denied, 429 U.S. 919 (1976); United States v. Delay, 500 F.2d 1360, 1365 (8th Cir. 1974) (judge should grant continuance "only where there is a reasonable likelihood that prejudicial news . . . will prevent a fair trial").

${ }^{37}$ See, e.g., Gannett Co. v. DePasquale, 443 U.S. 368, 379 n.5 (1979). The defendant may not obtain jury sequestration unless he shows prejudice. See, e.g., United States v. Kampiles, 609 F.2d 1233, 1241 (7th Cir.) (no abuse of discretion in denying jury sequestration where defendant does not show prejudice resulting from a failure to sequester), cert. denied, 446 U.S. 954 (1979); Mastrian v. McManus, 554 F.2d 813, 818-19 (8th Cir.) (other steps taken to mitigate the prejudicial effect of pre-trial publicity make jury sequestration unnecessary), cert. denied, 433 U.S. 913 (1977).

ss FED. R. CRIM. P. 21(a) provides for transferring the trial to another district "if the court is satisfied that there exists in the district where the prosecution is pending so great a prejudice against the defendant that he cannot obtain a fair and impartial trial at any place fixed by law for holding court in that district."

So FED. R. CRIM. P. 14 provides that the court may order a severance "[i]f it appears that a defendant or the government is prejudiced by a joinder."

60 The possibility of closure is most frequently raised with respect to pre-trial proceedings. See, e.g., Gannett Co. v. DePasquale, 443 U.S. 368, 390-91 (1979). Such closure is warranted whenever the defendant's right to a fair trial is likely to be jeopardized by adverse pre-trial publicity. Id. at 378-79; see id. at 400-01 (Powell, J., concurring). Closure of the trial itself is warranted only where the state's justification for denying access is a "weighty" one. Globe Newspaper Co. v. Superior Court, 457 U.S. 596, 606-07 (1982); see also Richmond Newspapers, Inc. v. Virginia, 448 U.S. 555, 581 (1980) ("Absent an overriding interest articulated in findings, the trial of a criminal case must be open to the public.").

o1 A gag order is available only if the defendant shows that, but for the order, a fair trial will be denied. Nebraska Press Ass'n v. Stuart, 427 U.S. 539, 569 (1976). Since even pervasive adverse pre-trial publicity "does not inevitably lead to an unfair trial," id. at 554, the requisite degree of certainty for obtaining a gag order may be all but impossible to demonstrate. See id. at 563-70.

Two other impartial jury safeguards-voir dire and retrial-are excepted from the present discussion because they do not enable a defendant who has already demonstrated partiality to avoid trial by a partial jury. The voir dire examination, with its attendant peremptory challenges and challenges for cause, is employed as a matter of course to prevent the impanelling of a partial jury. Thus, the voir dire examination is entirely prophylactic, and the successful demonstration of partiality presupposes its inadequacy. Cf. Irvin v. Dowd, 366 U.S. 717, 727-28 (1961) (where 90\% of the prospective jurors examined had some opinion as to the defendant's guilt, voir dire examination insufficient protection against partial trial). Retrial is appropriate where the trial judge erred in finding that prejudice had not been shown. See, e.g., id. at 728 (trial court erred in finding no prejudice). Thus retrials for partiality have been characterized as "palliatives" in comparison to "remedial measures that will prevent the prejudice at its inception." Sheppard v. Maxwell, 384 U.S. 333, 363 (1966). 
"would result"62 from the denial of his motion for a bench trial. In short, the fair trial guarantee only requires that a nonconsensual bench trial be available as a remedy of last resort.

To construe the fair trial guarantee as conferring upon the defendant the right to a bench trial while an impartial trial by jury is still available would offend the constitutional preference for the latter mode of trial. As the Court declared in Patton $v$. United States, ${ }^{63}$ the Constitution establishes trial by jury as the "normal and ... preferable mode of disposing of issues of fact in criminal cases . . . " Indeed, prior to Patton, waiver of trial by jury was deemed unconstitutional in felony cases. ${ }^{65}$ Given this preference, it is implausible to read the fair trial guarantee as requiring a bench trial where there are other procedures available to preserve both a defendant's right to a fair trial and the constitutional preference for trial by an impartial jury.

Since the fair trial guarantee does not give a defendant an affirmative constitutional right to a bench trial except where an impartial trial is otherwise impossible, ${ }^{66}$ making a nonconsensual bench trial a remedy of last resort cannot constitute a violation of that guarantee. Such a last-resort status is not without precedent. The Supreme Court has made two of the safeguards of jury impartiality remedies of last resort: gag orders and orders closing a trial to the public and the press. ${ }^{87}$ Indeed, one may well conclude that a defendant's failure to exhaust the alternative protections available to him is persuasive evidence that he himself regards his trial as fair. ${ }^{68}$

62380 U.S. at 37.

es 281 U.S. 276 (1930).

o4 Id. at 312 .

Bs See id. at 308-09; cases cited supra note 10.

${ }^{68}$ Singer, 380 U.S. at 34-35.

67 Closing a trial to the press and the public pits the defendant's right to a fair trial against another the public's right of access to the trial. Globe Newspaper Co. v. Superior Court, 457 U.S. 596 (1982); Richmond Newspapers, Inc. v. Virginia, 448 U.S. 555 (1980). As a consequence, any order closing a trial to the public is invalid without an inquiry into alternative means to preserve fairness. Richmond Newspapers, 448 U.S. at 580-81. Justice Powell has suggested that such an inquiry should also be required before determining whether or not to close a pretrial hearing. Gannett Co. v. DePasquale, 443 U.S. 368,400 (1979) (concurring opinion); see also United States v. Criden, 675 F.2d 550, 554-57 (3d Cir. 1982) (holding that the Richmond Newspapers right of access extends to pre-trial suppression, due process, and entrapment hearings).

Similarly, Nebraska Press Ass'n v. Stuart, 427 U.S. 534, 568-69 (1976), has held that a prior restraint on pre-trial reporting violates the first amendment if other reasonably efficacious measures for protecting the defendant against jury partiality are available.

${ }^{68}$ See, e.g., Beck v. Washington, 369 U.S. 541, 557-58 (1962) (defendant's failure to challenge jurors for cause is strong evidence that he was convinced they were not biased); 
The holdings of virtually all the cases analyzing the nonconsensual bench trial issue, despite their seeming obliviousness to the last-resort problem, are consistent with the last-resort analysis. Most of Singer's progeny denied the defendant's motion for a bench trial simply because the defendant failed to demonstrate sufficient prejudice on the part of the existing jury of the present venire. ${ }^{69}$ Thus, notwithstanding the lack of consensus as to the showing of prejudice required, none of these cases reached the lastresort issue. Suggestions that a stronger showing would have compelled a nonconsensual bench trial are only dicta. ${ }^{70}$

Of the four cases that did find the existence of sufficient jury prejudice and so logically should have reached the last-resort issue, only the court ${ }^{71}$ in United States $v$. Daniels ${ }^{72}$ refused to grant a nonconsensual bench trial, ruling that despite the threat of prejudice, a continuance would suffice to ensure a fair trial..$^{73}$ In contrast, each of the three other cases granted a nonconsensual bench trial without any intimation that alternative remedies were inadequate. On closer examination, however, only one of these rulings is inconsistent with the present treatment of the nonconsensual bench trial as a remedy of last resort.

In United States $v$. Schipani, ${ }^{74}$ the United States District Court for the Southern District of New York ruled that a bench trial was required both because the government could not withdraw its consent to the jury waiver, and, alternatively, because of the "substantial danger" of severe prejudice stemming from the government's theory of prosecution, which would inevitably apprise the jury of the defendant's ties to organized crime. ${ }^{75}$ Not only is the court's treatment of Singer an alternate holding and there-

United States ex rel. Darcy v. Handy, 351 U.S. 454, 463 (1956) (failure to exhaust the means provided to prevent an unfair jury trial, including exhausting the available peremptory challenges and seeking a continuance or a change of venue, while not dispositive, is significant indication that defendant regarded jury panel as impartial); Stroble v. California, 343 U.S. 181, 193-94 (1952) (petitioner's failure to move for a change of venue, while not dispositive, is significant in determining whether there was widespread community prejudice).

-S See supra notes 36-42 and accompanying text.

${ }^{70}$ See cases cited supra notes 34-35.

71 United States v. Braunstein, 474 F. Supp. 1 (D.N.J. 1979); United States v. Panteleakis, 422 F. Supp. 247 (D.R.I. 1976); United States v. Daniels, 282 F. Supp. 360 (N.D. Ill. 1968); United States v. Schipani, 44 F.R.D. 461 (E.D.N.Y. 1968). These cases are discussed supra notes 43-55 and accompanying text.

72282 F. Supp. 360 (N.D. Ill. 1968).

7s Id. at 361. For a discussion of this case, see supra text accompanying notes 52-55.

7444 F.R.D. 461 (E.D.N.Y. 1968). For a discussion of this case, see supra note 51 and text accompanying notes $47-51$.

${ }^{75}$ Id. at 463; see supra text accompanying notes $47-48$. 
fore of limited precedential value, ${ }^{76}$ but more importantly, the prejudice from the government's theory of prosecution was inherent in any jury trial. The tone of the court's statement that "no disinfecting admonition by the Court and no minor exclusions of evidence can prevent the jury from becoming aware of the stench [of organized crime]"77 confirms that the prior-resort remedies could not have cured the prejudice. Schipani, then, may be seen as an example of an implicitly successful last-resort showing.

United States $v$. Braunstein, ${ }^{78}$ a multiple defendant case, may also be reconciled with the last-resort analysis. In Braunstein the court stated that intricate evidentiary rulings and inherent factual complexity created a heavy risk of prejudice. ${ }^{79}$ Judge Biunno nevertheless rejected Singer as the ground of his decision to grant a bench trial," instead basing his holding on "a reading of Rule 23(a) together with Rule 2" of the Federal Rules of Criminal Procedure $^{\mathbf{}}{ }^{1}$ Because the source of prejudice to Braunstein was the joinder of his trial with the trials of his co-conspirators, a severance clearly would have been efficacious. Nonetheless, the explicit disavowal of any reliance on Singer makes it clear that the court was not recognizing any constitutional right to a bench trial as a remedy of first resort based on the fair trial guarantee.

The last of these cases, however, cannot be harmonized with Daniels and the last-resort analysis. In United States $v$. Panteleakis, ${ }^{82}$ another multiple defendant case, the same court that decided Schipani ruled that, since "substantial prejudice" from evidentiary rulings was "practically impossible to avoid," the showing of prejudice required by Singer was satisfied and a nonconsensual bench trial was therefore required. ${ }^{83}$ Since a severance would have alleviated the problem of prejudice, the court's holding is inconsistent with the conclusion that the fair trial guarantee requires a bench trial only as a remedy of last resort. However, since the court betrayed no awareness of the last-resort issue, the opinion is hardly an affirmative ruling on the question. It is rather, at most, an inconsistency resulting from inadvertence.

\footnotetext{
70 See supra note 51.

7744 F.R.D. at 463.

78474 F. Supp. 1 (D.N.J. 1979).

79 Id, at 14 .

so Id. at 12 .

s1 Id. at 14 .

422 F. Supp. 247 (D.R.I. 1976).

ss Id. at 248-250.
} 


\section{B. Violation of the Impartial Jury Guarantee}

While the due process guarantee of a fair trial does in fact carve out a constitutional exception to Rule 23(a)'s requirement of government consent, the last-resort nature of this exception renders it ultimately meaningless. In order to satisfy the last-resort showing, the defendant must demonstrate that any jury trial he could possibly receive-whether pursuant to a continuance, a change of venue, or any other remedial procedure-would necessarily be partial. ${ }^{84}$ Otherwise the government's refusal to consent would not subject the defendant to an unfair jury trial..$^{85}$ Yet by establishing that he cannot obtain an impartial jury under any circumstances the defendant has demonstrated a violation of his sixth amendment right to an "impartial jury."

While a literal reading of the sixth amendment would appear to compel this conclusion, two alternative interpretations of the "impartial jury" clause might avoid this result. Each of these alternatives, however, is inadequate. Under the first interpretation, the impartial jury provision, as well as article III's jury trial guarantee, could be construed as merely a means to a fair and impartial trial. This construction would suggest that where a jury trial would actually preclude a fair trial, a bench trial would work no constitutional deprivation on the defendant. Some credence is lent to this view by the Supreme Court's observation that the defendant's right to a fair trial is "the most fundamental of all freedoms."

Nevertheless, this interpretation suffers a number of shortcomings, not the least of which is that it effectively reads language out of the Constitution on the strength of a fair trial guarantee that the Constitution never explicitly protects. The importance of

st It is extremely unlikely that this showing could be made. The mere demonstration of partiality is itself quite difficult, as is demonstrated by the post-Singer case law. See supra notes 36-42 and accompanying text. Meeting the second part of the Singer test, the lastresort showing, borders on the impossible, as is indicated by the dearth of cases that, acknowledging the inadequacy of all of the impartial-jury safeguards, have ordered dismissal. See infra notes 94-96 and accompanying text; see also Nebraska Press Ass'n v. Stuart, 427 U.S. 539, 603 n.30 (1976) (Brennan, J., concurring) ("[I]n no decision of this Court has it been necessary to release an accused on the ground that an impartial jury could not be assembled . . . ."); id. at 603-04. ("[T] The traditional techniques . . . for ensuring fair trials would have been adequate in every case in which we have found that a new trial was required due to lack of fundamental fairness to the accused."). However, it may well be that if only a nonconsensual bench trial were at stake, rather than the drastic remedy of dismissal, courts would be less reluctant to rule that the prior-resort remedies were inadequate.

ss See supra notes 56-62 and accompanying text.

s6 Estes v. Texas, 381 U.S. 532, 540 (1965); see Dennis v. United States, 339 U.S. 162, 173 (1950) (Jackson, J., concurring) ("The right to fair trial is the right that stands guardian over all other rights."). 
the jury trial has been repeatedly emphasized by the Supreme Court: trial by jury in serious criminal cases is an "indispensable protection" of the accused, ${ }^{87}$ and has been held so "fundamental to the American scheme of justice" as to be incorporated into the due process clause of the fourteenth amendment. ${ }^{88}$ Moreover, the jury trial is a "privilege of the accused" that only he can waive. ${ }^{89}$ Given this right of the defendant, the Supreme Court has noted that a bench trial "can hardly serve as a substitute for a jury trial." nally, the purpose of the constitutional guarantee of a jury trial is not simply to promote fairness. The jury trial guarantee reflects " $a$ fundamental decision about the exercise of official power" evincing a reluctance to entrust the life and liberty of citizens to judges alone and an "insistence upon community participation in the determination of guilt or innocence." guarantee, though insufficient to prohibit jury waiver completely, prevents the guarantee from being construed as a mere means to the end of a fair trial.

Under the second interpretation of the sixth amendment, the defendant's right to an impartial jury could be construed as a relative rather than an absolute right. As with the defendant's related right to a speedy trial, ${ }^{92}$ whether or not a defendant's right to an impartial jury has been violated would be determined by weighing the sacrifice the government would have to make to prevent parti-

87 Brown v. Louisiana, 447 U.S. 323, 330 (1980) (plurality opinion of Brennan, J., three Justices concurring); see also Nebraska Press Ass'n v. Stuart, 427 U.S. 539, 572 (1976) (Brennan, J., concurring) ("iight to a fair trial by a jury of one's peers is unquestionably one of the most precious and sacred safeguards enshrined in the Bill of Rights"); Irvin v. Dowd, 366 U.S. 717, 721 (1961) (Trial by jury is "the most priceless" safeguard of individual liberty.).

ss Duncan v. Louisiana, 391 U.S. 145, 149 (1968). Contrast, however, the observation of Justice Cardozo that few people would be "so narrow or provincial as to maintain that a fair and enlightened system of justice would be impossible without [juries]." Palko v. Connecticut, 302 U.S. 319,325 (1937).

89 Patton v. United States, 281 U.S. 276, 296-97 (1930).

${ }^{\text {so }}$ Baldwin v. New York, 399 U.S. 66, 72 n.20 (1970) (plurality opinion of White, J., three Justices concurring).

ol Duncan v. Louisiana, 391 U.S. 145, 156 (1968); see also Baldwin v. New York, 399 U.S. 66, 72 (1970) (plurality opinion of White, J., three Justices concurring) ("jury interposes between the accused and his accuser the judgment of laymen who are less tutored perhaps than a judge or panel of judges, but who . . . are less likely to function or appear as but another arm of the Government"); Williams v. Florida, 399 U.S. 78, 100 (1970) (jury promotes "community participation and shared responsibility").

${ }^{82}$ In Barker v. Wingo, 407 U.S. 514 (1972), the Supreme Court expressly ruled that, in determining whether a defendant's speedy trial right has been violated, a court should weigh four factors reflecting the conduct of both the prosecutor and the defendant: the length of the delay, the reason for the delay, whether the defendant in fact asserted his right, and the degree of prejudice to the defendant. Id. at 529-30. 
ality against the magnitude of the harm that the defendant would otherwise suffer. Thus, where pre-trial publicity has hopelessly prejudiced all available jurors, the court might nonetheless be justified in deeming the jury sufficiently impartial to avoid the drastic remedy of dismissal.

This construction, however, by suggesting that one and the same jury may be sufficiently partial to require a nonconsensual bench trial yet sufficiently impartial to bar a dismissal, renders the meaning of the impartial jury clause disturbingly manipulable. Even where the question of a constitutional right has been held "necessarily dependent" on particular circumstances, as with the speedy trial guarantee, ${ }^{93}$ the answer to the question does not vary with the remedy sought. ${ }^{94}$ Interpreting the sixth amendment as a relative guarantee, however, by allowing the definition of impartiality to change according to the relief requested, would have precisely this flaw.

\section{Availability of Dismissal}

Once it has been shown that the sixth amendment right to an impartial jury is neither a subsidiary nor a relative right, the issue arises whether a finding that it is impossible to guarantee this right warrants dismissal. This question has seldom been treated in the case law, in part because courts rarely find that an impartial jury is unobtainable. ${ }^{85}$ Nevertheless, at least one federal indictment has been dismissed on the ground that prejudicial pre-trial publicity prevented the impanelling of an impartial jury, ${ }^{96}$ and two other

93 Id. at $530-31$.

* Indeed, dismissal is the only possible remedy for violations of a defendant's right to a speedy trial. Strunk v. United States, 412 U.S. 434, 440 (1973).

ss See, e.g., United States v. Stanford, 589 F.2d 285, 299 (7th Cir. 1978) (denial of motion to dismiss on grounds of prejudicial pre-trial publicity where insufficient showing of prejudice), cert. denied, 440 U.S. 983 (1979); United States v. Abbott Laboratories, 505 F.2d 565,572 (4th Cir. 1974) (reversal of lower court's dismissal of indictment because defendant did not demonstrate the prejudicial nature of pre-trial publicity convincingly enough), cert. denied, 420 U.S. 990 (1975); United States v. Zovluck, 274 F. Supp. 385, 389-90 (S.D.N.Y. 1967) (refusing to grant dismissal on grounds of publicity where publicity did not prejudice jurors); supra note 84 . Of the four post-Singer cases holding that the defendant had established partiality, see supra text accompanying notes 71-83, only one, United States v. Schipani, 44 F.R.D. 461 (E.D.N.Y. 1968), even implicitly found the impanelling of an impartial jury to be impossible. See supra notes 74-77 and accompanying text.

* United States v. Cotton, No. 68-113, slip op. (E.D. Wis. June 11, 1969), appeal dismissed, 397 U.S. 45 (1970); see Transcript Dismissing Federal Indictment-Milwaukee 14, 28 GuILd Prac. 101 (1969). The defendants were a group of Catholic priests and laymen who broke into a Selective Service office and burned the files of draftees classified 1-A. All except one refused to request a change of venue. Id. at 101. The Supreme Court, with Justice 
federal cases have suggested the availability of dismissal where an impartial jury cannot be obtained..$^{97}$

Support for a dismissal as the remedy for the impossibility of satisfying the impartial jury guarantee may also be found in cases treating violations of the right to a speedy trial. Dismissal has been well-recognized as "the only possible remedy" for the denial of the defendant's right to a speedy trial-a right which the sixth amendment confers in the same clause that creates the impartial jury guarantee. Of course, a necessary violation of the speedy trial right is established retrospectively, whereas a defendant who makes the last-resort showing must demonstrate a prospective violation of his right to an impartial jury. Once the defendant has demonstrated that no procedure could possibly preserve an impartial jury, however, this prospective denial is inevitable and the retrospective-prospective distinction loses significance. In both cases, the defendant has established a necessary violation of his constitutional rights. Thus the availability of dismissal for a violation of the defendant's right to a speedy trial suggests that the remedy would be appropriate for a denial of the impartial jury guarantee as well.

Most importantly, dismissal is required in order to avoid vitiating the impartial jury guarantee. The possibility of dismissal does not arise unless all other remedies for jury partiality have been shown to be futile. If the unavailability of an impartial jury is occasion enough to try the protesting defendant before a partial jury or the bench, the clause is bypassed precisely where the defendant is most in need of its protection.

\section{The Possibility of Waiver}

If the last-resort showing demonstrates the violation of the defendant's right to an impartial jury, and if dismissal is available as a remedy for such violation, the only possibility of giving meaning to a defendant's right to a nonconsensual bench trial based on the

Douglas dissenting, dismissed the appeal for failure to docket the case within prescribed time limits. 397 U.S. at 45.

${ }^{97}$ United States v. Abbott Laboratories, 505 F.2d 565, 571-72 (4th Cir. 1974), cert. denied, 420 U.S. 990 (1975); United States v. Smith, 200 F. Supp. 885, 933 (D. Vt.), rev'd, 306 F.2d 596 (2d Cir. 1962). Although the Smith case was reversed by the Second Circuit on the ground that the defendant had not been tried by a prejudiced jury, $306 \mathrm{~F} .2 \mathrm{~d}$ at 602 , the reasoning of the lower court-that once the damage of partiality has been done it is at best doubtful that the restoration of fundamental constitutional rights can be achieved by the impartial jury safeguards-is noteworthy.

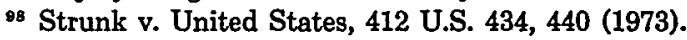


fair trial guarantee is to deem the defendant to have waived the right to an impartial jury and thus the opportunity for dismissal. Such a characterization is unsupportable under current waiver analysis.

In Johnson v. Zerbst, ${ }^{90}$ the Supreme Court held that a valid waiver of a fundamental constitutional right requires the "intentional relinquishment or abandonment of a known right or privilege." 100 To satisfy this standard, a waiver must be voluntary ${ }^{101}$ or, as one circuit has noted, must involve "the free exercise of an uncoerced will, and conduct ... which evidences an intent to waive."102 Under Zerbst a defendant who fears a partial jury trial cannot be deemed to have waived his right to an impartial jury simply because he sought a nonconsensual bench trial. The defendant's waiver motion presumably springs from his desire to limit his losses; by foregoing his doomed jury trial he can at least preserve his right to a fair trial. Such a waiver motion is coerced by the prospect of partiality and thus does not satisfy the requirement under Zerbst that a waiver be voluntary. ${ }^{103}$

Since a defendant who makes the last-resort showing has not waived his right to dismissal simply by moving for a bench trial, he is certain to discard this hard-won right to a nonconsensual bench trial at the moment of its vesting. The possibility raised by Singer, therefore, simply does not exist: the fair trial limitation on the prosecution's power to block a bench trial is illusory.

90 304 U.S. 458 (1938).

$100 \mathrm{Id}$. at 464.

101 See Boykin v. Alabama, 395 U.S. 238, 242, 244 (1969); McCarthy v. United States, 394 U.S. 459, 466 (1969); see also Barker v. Wingo, 407 U.S. 514, 529 (1972) (waiver of "fundamental rights" must be voluntary).

${ }^{102}$ United States v. Marcello, 423 F.2d 993, 1004 (5th Cir.), cert. denied, 398 U.S. 959 (1970).

${ }^{103}$ One might argue, based on an analogy to courts' treatment of change of venue motions, that a defendant's motion for a bench trial constitutes a waiver of his jury right. Generally, a defendant who moves for a change of venue in order to avoid a partial venire is deemed to have waived his article III venue right and his sixth amendment vicinage right. See infra note 122. The analogy, however, appears unconvincing when one compares the nature of the rights at issue in the two instances. A defendant who moves for a bench trial would under this analogy be forced to waive his right to a jury trial; the defendant moving for a change of venue however, is only forced to waive his vicinage right. While the latter right is an important one, see infra notes $121-26$ and accompanying text, it is surely less important than the jury trial guarantee. See supra notes $87-91$ and accompanying text. Because the stakes are higher, the defendant's motion to waive jury trial cannot be viewed as "the free exercise of an uncoerced will." 


\section{What Singer OverLooks}

While the defendant's right to a fair trial never meaningfully entitles him to obtain a nonconsensual bench trial, it does not follow that Rule 23(a)'s requirement of government consent is without other constitutional limitations. This section compares the interests infringed by the nonconsensual bench trial to the interests infringed by each of the other impartial jury safeguards, and argues that the Constitution mandates that a defendant be permitted to elect a bench trial whenever he is entitled to any safeguard that would infringe substantial constitutional interests; in particular, this section argues that a defendant must be permitted to elect a nonconsensual bench trial even where a change of venue, closure, or a gag order would preserve his right to a fair trial. It concludes by pointing out that this requirement, unlike the right to a nonconsensual bench trial based on the fair trial guarantee contemplated in Singer, has practical significance.

Seven potential remedies exist for jury partiality. First, there are six safeguards that remedy partiality while preserving trial by jury: jury sequestration, severance, continuance, change of venue, closure, and gag orders. Second, if a defendant is willing to waive his right to a jury trial ${ }^{104}$ a bench trial can be ordered to preserve his unwaived right to a fair trial. Each of these seven remedies counters the impending violation of the defendant's right to an impartial jury at the cost of impinging on interests of the defendant, the prosecution, the press, or the public. Because the interests infringed by a nonconsensual bench trial are less important than the constitutional interests infringed by several of the other six remedies, a defendant should be permitted to elect a nonconsensual bench trial whenever his right to a fair trial can otherwise be preserved only by resort to a remedy which impinges on one of these more important interests. The requirement of government consent imposed by Rule 23(a), then, must be limited, not, as Singer suggests, to preserve the defendant's fair trial guarantee, but to protect constitutional interests impinged on by alternative remedies.

Granting a nonconsensual bench trial arguably impinges two interests. First, it stymies a constitutional preference for trial by jury. Trial by jury, Singer notes, has been established by the Constitution as the "normal and ... preferable mode of disposing of

104 The defendant, of course, cannot be forced to waive trial by jury. See supra note 89 and accompanying text. 
issues of fact in criminal cases." "10s Yet in Patton $v$. United Siates, ${ }^{106}$ from which Singer quotes this passage, the Court went to great lengths to demonstrate that the jury trial provision of article III" ${ }^{107}$ "is not jurisdictional but was meant to confer a right upon the accused which he may forego at his election." ${ }^{108}$ To deny "his power to do so," the Court continued, "is to convert a privilege into an imperative requirement." 109 Thus the constitutional preference for jury trial that Patton articulates is significantly qualified by the very holding of the decision itself; the defendant's power to waive a jury trial outweighs the Constitution's preference for a jury trial..$^{110}$

Second, the nonconsensual bench trial infringes the government's interest in jury trial recognized in Patton ${ }^{111}$ and by Rule 23(a). Yet as argued below in Part IV, this mere statutory ${ }^{112}$ interest of the government is far from a compelling one; whatever legitimate adversarial interest the government may have in resisting the defendant's bench trial motion is overborne by a defendant's demonstration of partiality. ${ }^{113}$

Balanced against these two interests are the interests impinged on by each of the six impartial jury safeguards. Three of these safeguards-jury sequestration, severance, and continuance-infringe no constitutional interests at all and thus do not impose constitutional limits on the government's power to veto a bench trial. Resort to jury sequestration and severance implicates

108 Singer v. United States, 380 U.S. 24, 35 (1965) (quoting Patton v. United States, 281 U.S. 276, 312 (1930)).

108281 U.S. 276 (1930).

107 U.S. ConsT. art. III.

${ }^{108} 281$ U.S. at 298. The Court's conclusion embraces the sixth amendment jury trial provision as well since the Court states that the sixth amendment "is not to be regarded as modifying or altering" the article III provision; rather, "the two provisions mean substantially the same thing ...." Id.

${ }^{100} \mathrm{Id}$.

110 Compare the discussion supra text accompanying notes 63-65 where it is argued that the Constitution's preference for trial by jury bolstered the conclusion that the fair trial guarantee does not require a bench trial except as a remedy of last resort. The present discussion is not inconsistent with that argument, since it only seeks to establish the attenuated nature of the constitutional preference, not the absence of the preference.

11281 U.S. at 312.

112 Under 18 U.S.C. $\$ 3771$ (1982), Congress was formerly deemed to have adopted the Federal Rules of Criminal Procedure, thus arguably endowing them with the same force as statutes. See supra note 15 . The Supreme Court's decision in INS v. Chadha, $103 \mathrm{~S}$. Ct. 2764 (1983), declaring the legislative veto unconstitutional may cast doubt on this conclusion. In any case, Rule $23(\mathrm{a})$ can safely be said to confer no more than a statutory interest upon the government.

11 See infra notes 144-71 and accompanying text. 
only concerns of convenience and judicial economy. ${ }^{114} \mathrm{~A}$ continuance, by contrast, implicates the defendant's sixth amendment right to a speedy trial. ${ }^{115}$ However, where a continuance is employed as a remedy for partiality, it is highly unlikely that it would actually violate the defendant's speedy trial right. In Barker $v$. Wingo, ${ }^{116}$ the Supreme Court held that whether a delay violates a defendant's right to a speedy trial depends in part on the reason for the delay and on the existence of actual prejudice to the defendant as a result of the delay. ${ }^{117}$ The Court noted that a deliberate attempt by the government to delay the trial in order to hamper the defendant "should be weighed heavily against the government," that a "more neutral reason" such as negligence or overcrowded courts should be weighed less heavily, and that "a valid reason, such as a missing witness, should serve to justify appropriate delay." 118 The Court also described the illness of the exsheriff in charge of the investigation in Barker as a "strong excuse"118 for a continuance. Assuming the prosecution was not responsible for creating the risk of prejudice, a delay imposed to abate potential prejudice appears to be strongly justified and therefore not violative of the defendant's speedy trial right. ${ }^{\mathbf{1 2 0}}$

The three remaining impartial jury safeguards-change of venue, closure, and gag orders-infringe substantial constitutional interests that outweigh the interests affected by the nonconsensual bench trial. Change of venue necessarily entails the sacrifice of a defendant's sixth amendment right to a jury of "the State and district wherein the crime shall have been committed"121 and is available only upon the defendant's request. ${ }^{122}$ The Supreme Court has explained that this provision, together with the requirement of ar-

114 Jury sequestration, of course, inconveniences the jurors while severance requires multiple trials.

11 U.S. Const, amend. VI.

118407 U.S. 514 (1972).

${ }^{117}$ Id. at 530. The Court also mentioned two other factors: the length of the delay and whether the defendant had asserted his right to a speedy trial. Id.

118 Id. at 531.

118 Id. at 534 .

${ }^{120}$ If, despite these observations, the continuance required in an extraordinary case were in fact to threaten the defendant's speedy trial right, that defendant should be offered the option of a nonconsensual bench trial.

121 U.S. CoNST. amend. VI; see supra note 9.

${ }^{122}$ FED. R. CRIM. P. 21 provides for a change of venue only upon the defendant's motion, because, as the advisory committee explained, "the defendant has a constitutional right to a trial in the district where the offense was committed." The committee adds that, by making a change of venue motion, the defendant waives his venue right. Fen. R. CRIM. P. 21 advisory committee note 3. 
ticle III that all criminal jury trials "shall be held in the State where the said Crimes shall have been committed,"123 is designed to prevent "the needless hardship to an accused by prosecution remote from home and from appropriate facilities for defense."124 Changes of venue ${ }^{125}$ in criminal cases, then, "are not merely matters of formal legal procedure" but "raise deep issues of public policy."128

Closure also impinges on constitutionally protected interests of the defendant and, in addition, infringes constitutionally protected interests of nonparties. Closure deprives the accused of his sixth amendment right to a "public trial,"127 a right that "has always been recognized as a safeguard against any attempt to employ the courts as instruments of persecution"128 and has therefore been incorporated into the fourteenth amendment's due process clause. ${ }^{129}$ Closure also impinges upon the first amendment right of the press and the general public of access to criminal trials, ${ }^{130}$ which serves to foster the informed discussion of governmental affairs. ${ }^{131}$ While the right is not absolute, any justification for denying access "must be a weighty one."132

128 U.S. Const. art. III, $\S 2$, cl. 3.

124 United States v. Johnson, 323 U.S. 273, 275 (1944); accord Travis v. United States, 364 U.S. 631, 634 (1961).

125 Technically, only the article III guarantee is a venue provision; the sixth amendment guarantee is a vicinage provision. See Kershen, Vicinage (pts. 1 \& 2), 29 OKLA. L. REv. 801 (1976), 30 OkLA. L. REv. 1 (1977). The Supreme Court generally refers to the two clauses collectively as "venue" provisions. See, e.g., United States v. Johnson, 323 U.S. 273, 276 (1944).

126 United States v. Johnson, 323 U.S. 273, 276 (1944); accord Travis v. United States, 364 U.S. 631, 634 (1961).

127 U.S. ConST. amend. VI. Closure is typically applied to pre-trial hearings and not to the trial itself. See supra note 60 . While the Supreme Court has never directly addressed the issue, lower courts have unanimously held that pre-trial suppression hearings fall within the accused's public-trial guarantee. See, e.g., United States v. Cianfrani, 573 F.2d 835, 850 (3d Cir. 1978); United States v. Clark, 475 F.2d 240, 247 (2d Cir. 1973); United States ex rel. Bennett v. Rundle, 419 F.2d 599, 606 (3d Cir. 1969) (en banc); United States v. Lopez, 328 F. Supp. 1077, 1087 (E.D.N.Y. 1971).

128 In re Oliver, 333 U.S. 257, 270 (1948).

129 Id. at 273.

1s0 Globe Newspaper Co. v. Superior Court, 457 U.S. 596, 603 (1982).

1si Id. at 604-05.

1s2 Id. at 606. In Globe, the Supreme Court held that a state statute requiring mandatory exclusion of the press and general public from the courtroom during the testimony of minor victims of specified sexual offenses was unconstitutional. The Court determined that neither the state's interest in protecting such victims from further trauma and embarrassment nor its interest in encouraging of such victims to come forward justified a mandatory exclusion rule. Id. at 607-611. A "presumption of openness," said the Court, "inheres in the very nature of a criminal trial under our system of justice." Id. at 610 (quoting Richmond Newspapers, Inc. v. Virginia, 448 U.S. 555, 573 (1980)). 
Finally, gag orders, like closure, infringe vital first amendment interests of nonparties. In Nebraska Press Association v. Stuart, ${ }^{\mathbf{1 3 3}}$ the Supreme Court declared prior restraints to be "the least tolerable infringement" of first amendment rights and held that the presumption against their validity "should have particular force as applied to reporting of criminal proceedings."134 Because gag orders mitigate the prejudicial effects of trial publicity only at the expense of infringing the constitutional rights of nonparties, they have been treated as a remedy of last resort for ensuring a fair trial. ${ }^{135}$

Given the substantial constitutional interests infringed by these three remedies, the nonconsensual bench trial must be available as a prior remedy. Yet, at least with respect to closure and change of venue, it might be argued that this right, like a right based on the fair trial guarantee, is irrelevant. Since closing a trial or changing its venue infringes significant constitutional interests of the defendant, then arguably the defendant should never be forced to resort to either of these remedies to obtain his constitutional right to an impartial jury. ${ }^{138}$ The defendant confronted with a choice between losing his vicinage or public trial right and his impartial jury guarantee should be able to stand on both and obtain dismissal.

If the defendant is rightfully entitled to dismissal, he certainly will not seek a bench trial. Thus, if the foregoing argument were correct, the availability of a nonconsensual bench trial based on the constitutional rights impinged on by alternative remedies, like the right based on the fair trial guarantee, would be irrelevant save in the narrow circumstance when the defendant is entitled to a gag order. ${ }^{137}$

This argument, though not without force, is ultimately unpersuasive. It does not follow from the availability of dismissal for the denial of the right to an impartial jury that dismissal is likewise available for the denial either of the defendant's right to a jury of the vicinage or his right to a public trial. Nor does it follow that because these two latter rights outweigh the government's interest

1ss 427 U.S. 539 (1976).

134 Id. at 559.

135 Id. at $563-65$.

${ }^{1 s 8}$ Cf. Simmons v. United States, 390 U.S. 377, 394 (1968) (Court holds it "intolerable that one constitutional right should have to be surrendered in order to assert another" in situation where defendant was obliged either to surrender a fourth amendment claim or waive his fifth amendment privilege against self-incrimination).

137 See supra notes 133-35 and accompanying text. 
in being able to force a jury trial by withholding consent to a bench trial, ${ }^{138}$ they therefore are important enough-as is the impartial jury guarantee-to require preservation by dismissal.

The Supreme Court has described the jury trial right as an "indispensable protection" of the accused"139 and as "the most priceless" safeguard of individual liberty. ${ }^{140}$ In contrast, the Court has betrayed a considerably less protective approach to the vicinage right; by treating defendant's failure to move for a change of venue as strongly probative of the lack of widespread local prejudice, the court has effectively encouraged the defendant to waive his vicinage right. ${ }^{141}$ In regard to the public trial right, lower federal courts have permitted the limited exclusion of the public from the trial over the defendant's objection, ${ }^{142}$ and the Supreme Court has described the public trial guarantee in markedly less emphatic terms than the jury trial right. ${ }^{143}$ Therefore, the availability of the nonconsensual bench trial as a remedy of prior resort is not irrelevant because, unlike the defendant confronted with a choice between a fair trial and an impartial jury, the defendant who must choose merely between a change of venue or closure and a fair jury trial is not entitled to dismissal.

\section{Modifying the Rule 23(A) Requirement of Government CONSENT}

Under the present Rule 23(a), the government's power of nonconsent, though subject to constitutional restrictions, retains significant force. Constitutionally protected interests of both the pub-

138 See supra notes 121-36 and accompanying text.

2s9 Brown v. Louisiana, 447 U.S. 323, 330 (1980) (plurality opinion of Brennan, J., three Justices concurring).

${ }^{140}$ Irvin v. Dowd, 366 U.S. 717, 721 (1961); see also supra note 87.

${ }^{141}$ See supra note 68. Indeed, there has been only one reported federal case dismissing a prosecution on the ground of jury partiality where the defendants refused to move for a change of venue. See United States v. Cotton, No. 68-113, slip op. (E.D. Wis. June 11, 1969), appeal dismissed, 397 U.S. 45 (1970).

162 See United States ex rel. Lloyd v. Vincent, 520 F.2d 1272, 1274 (2d Cir.) (exclusion from trial to preserve confidential identities of undercover agents), cert. denied, 423 U.S. 937 (1975); United States v. Bell, 464 F.2d 667, 669-70 (2d Cir.) (exclusion from pretrial hearing to preserve confidentiality of domestic security investigations), cert. denied, 409 U.S. 991 (1972); United States ex rel. Bruno v. Herold, 408 F.2d 125, 127-28 (2d Cir. 1969) (partial exclusion from trial to prevent witness from being intimidated), cert. denied, 397 U.S. 957 (1970); United States ex rel. Orlando v. Fay, 350 F.2d 967, 971 (2d Cir. 1965) (same), cert. denied, 384 U.S. 1008 (1966).

${ }^{143}$ Compare Brown v. Louisiana, 447 U.S. 323, 330 (1980) (jury trial is an "indispensable protection of the accused") with In re Oliver, 333 U.S. 257, 270-72 (1948) (Public trial is "an effective restraint on possible abuse of judicial power."). 
lic and the defendant can overcome the Rule 23(a) consent requirement, but only after severance, jury sequestration, and continuance have proven inadequate to stem partiality. ${ }^{144}$ The rule thus continues to limit the defendant's election of remedies for partiality. While it may not be objectionable to require the court to approve the defendant's election of a bench trial, ${ }^{145}$ to permit the government, an adverse party, to veto it even though the defendant has demonstrated partiality extends the government's interest in trial by jury beyond its justification. This section examines the rationale of the government consent requirement and proposes

144 See supra notes 104-43 and accompanying text.

143 The difficulty with requiring government consent-that it allows the adverse party to foist an at least initially partial jury on the defendant simply as a "litigation strategy," see infra notes 158-71 and accompanying text-does not obtain with respect to the requirement of court consent. Not only is the court not an adverse party, but, in practice, judges have virtually never refused to approve a jury waiver. In only three cases considering the nonconsensual bench trial issue is there even a hint that the court might have withheld consent. United States v. Joyce, 499 F.2d 9, 21 (7th Cir.) (court refused to sever trial even though two of the three co-defendants wanted a bench trial), cert. denied, 419 U.S. 1031 (1974); United States v. Wright, 491 F.2d 942, 945 (6th Cir.) (fact of government consent never expressly mentioned), cert. denied, 419 U.S. 862 (1974); Thwing v. South Dakota, 470 F.2d 351, 353 (8th Cir. 1972) (same), cert.denied, 411 U.S. 937 (1973). Moreover, just as Fed. R. CRIM. P. 11(d) prevents the court from accepting a plea of guilty or nolo contendere until it has advised the defendant of his rights and determined that the plea is voluntary, so the requirement of court consent to jury waiver allows the court to protect the defendant from an ill-advised waiver. Finally, given the federal judiciary's responsibility for supervision of the administration of criminal justice in the federal courts, see, e.g., McNabb v. United States, 318 U.S. 332, 340 (1943), the court is the proper organ for balancing the constitutional preference for and institutional benefits of jury trials against the defendant's desire to waive a jury trial. See infra notes $148-55$ and accompanying text.

Although commentators generally agree in their criticism of the Rule 23(a) requirement of government consent, only one commentator has explicitly rejected the requirement of court consent. Stewart, Comments on Federal Rules of Criminal Procedure, 8 J. MAR. L. Q. 296, 301 (1943); cf. Comment, Waiver of Jury Trials, supra note 24, at 1109-1112 (arguing that once the defendant has shown a reasonable likelihood of partiality, he should then have an "absolute right" to waive a jury trial). Other commentators criticize only the requirement of government consent and do not object to the requirement of court approval. Note, Waiver Following Waiver of Counsel, supra note 24, at 399; 51 CoRNzLL L. Q. 339, 345-46 (1966); see also Comment, The Government's Interest, supra note 24, at 772-73 (questioning the wisdom of requiring government consent). A third group takes a middle stand, rejecting the requirement of government consent altogether while advocating the requirement of court consent for the limited purpose of ensuring that the defendant's waiver is intelligently made. Donnelly, supra note 24, at 256; Orfield, Trial by Jury in Federal Criminal Procedure, 1962 DukE L.J. 29, 75; Comment, Burden of Prejudice, supra note 24, at 992-93; Note, Government Consent, supra note 24, at 1042; 60 Nw. U. L. REv. 722, 730 (1965). Finally, two commentators have suggested that a balancing procedure be adopted in which the government's reasons for a jury trial are weighed against the defendant's reasons for a bench trial. Comment, Waiver of Jury Trials, supra note 24, at 1109-1112; Note, Federal Rule 23(a), Government Consent Requirement in the Waiver of Jury Trial: Singer v. United States, 12 UCLA L. REv. 189, 198-99 (1965). 
that Rule 23(a) be amended to suspend this requirement upon the defendant's showing of partiality.

The Supreme Court has offered a number of rationales for conditioning the defendant's jury waiver on the consent of the government. These arguments appear in Patton $v$. United States ${ }^{146}$ as well as in Singer. Patton was the first instance in which the Supreme Court acknowledged that the defendant could waive his right to a jury trial with the consent of the government and the court. The Court's opinion suggested two rationales for the requirement of government consent. The first was the observation that trial by jury is "the normal, and with occasional exceptions, the preferable mode of disposing of issues of fact" in serious criminal cases. ${ }^{147}$ The Court stressed that "maintenance of the jury as a fact finding body in criminal cases . . . has such a place in our traditions" that the waiver of that procedure should not be entrusted to the defendant alone. ${ }^{148}$

These observations, true though they may be, are considerably less than compelling. While the historical importance of trial by jury may supply an argument against permitting the defendant to waive this right, it does not establish a reason for making the government either the beneficiary or the safekeeper of the traditional importance of trial by jury. The Court in Patton simply assumed that the preference for trial by jury creates a specific governmental interest in the jury trial. Given that the Court also required judicial consent to any jury waiver, which would appear adequate to safeguard any such interest, this first justification is all the more inadequate.

Patton suggested a second justification for the requirement of government consent by its remark that "[ $t]$ he state [and] the public, have an interest in the preservation of the liberties and the lives of the citizens, and will not allow them to be taken away without 'due process of law.' "148 However, the Court itself rejected this argument, reasoning that since the state could not prevent the

146 281 U.S. 276 (1930); see supra text accompanying notes 11-14.

167281 U.S. at 312.

148 Id. The government's brief in Singer fleshes this argument out, suggesting not only that juries may decide certain factual issues "more wisely than a judge," Brief for the United States at 27, Singer v. United States, 380 U.S. 24 (1965), but also that the jury serves to legitimate judicial proceedings, thus increasing public confidence in the administration of justice, $i d$. at 28. Finally, the brief maintains that "a collective group sometimes may be less likely than a single individual to yield to community pressures, either to acquit or to convict." Id.

140281 U.S. at 302 (quoting Cancemi v. People, 18 N.Y. 128, 137 (1858)). 
accused from altogether dispensing with a trial by pleading guilty it should not be able to "interpose the claim of public interest" between the accused and his ability to waive trial by jury. ${ }^{150}$ Even accepting the public interest in protecting the accused from an illadvised waiver, ${ }^{151}$ assigning the responsibility of protecting the defendant to the prosecuting attorney-the adverse party-is most peculiar. ${ }^{152}$ Not only does the requirement of court consent render the government's consent unnecessary to this end, but both Pat$\operatorname{ton}^{153}$ and the doctrine of waiver ${ }^{154}$ independently require the defendant's election to be knowing and intelligent. The requirement of government consent is even more superfluous given that the sixth amendment entitles the defendant to the advice of counsel in regard to his waiver. ${ }^{155}$

Beyond the demonstrated inadequacy of these two justifications, however, the consent requirement announced in Patton would vitiate the very reasoning upon which the Court based its holding. In declining to prohibit the defendant's waiver flatly, the Court found that trial by jury was a "valuable privilege bestowed upon the person accused of crime for the purpose of safeguarding him against the oppressive power of the King," not "part of the structure of government." the accused "which he may forego at his election. To deny his power to do so is to convert a privilege into an imperative requirement."187 The Court's insistence on government consent, however, effectively promotes this very result.

In contrast to Patton, Singer sets forth a more adequate justification for the requirement of consent by the government qua prosecution:

The Constitution recognizes an adversary system as the proper method of determining guilt, and the Government, as a litigant, has a legitimate interest in seeing that cases in which it believes a conviction is warranted are tried before the tribu-

160 Id. at 305.

${ }^{151}$ The government failed to address this issue in its brief in Singer. Brief for the United States at 12, Singer v. United States, 380 U.S. 24 (1965).

${ }^{162}$ For commentators supporting this position, see sources cited supra note 145.

153281 U.S. at 312.

${ }^{154}$ Johnson v. Zerbst, 304 U.S. 458, 464 (1938); see supra notes 99-102.

${ }^{265}$ See Mempa v. Rhay, 389 U.S. 128, 134 (1967) (sixth amendment entitles indigent defendants to court-appointed counsel "at every stage of a criminal proceeding where substantial rights of a criminal accused may be affected").

${ }^{18 B} 281$ U.S. at 296.

187 Id. at 298. 
nal which the Constitution regards as most likely to produce a fair result. This recognition of the Government's interest as a litigant has an analogy in Rule 24(b) of the federal rules, which permits the Government to challenge jurors peremptorily. ${ }^{158}$

Insofar as the "fair result" that a jury trial is likely to produce means fairness to the defendant, the Court's argument is simply a restatement of the "public interest" argument rejected in Patton. Insofar as the "fair result" means fairness to the government, Singer poses a new rationale based on the government's legitimate adversarial interests as a party litigant. Indeed, the government's brief in Singer expressly acknowledges that the prosecutor's consent decision "may be based largely on considerations of litigation strategy-that is, his judgment as to which mode of trial offers the best prospect of success," and argues that it is the prosecutor's " 'duty ... to use every legitimate means to bring about a just [conviction]." "158 The brief observes that "[p]articular judges may have the reputation of having fixed attitudes toward certain types of cases and individuals" and concludes that the public interest requires not only fairness to the accused but also "fairness to the prosecution in order to insure that the guilty do not improperly escape just punishment for their crimes." 160

This justification is subject to an important qualification. Berger $v$. United States, ${ }^{161}$ which the government's brief cited in support of its "litigation strategy" argument, ${ }^{162}$ establishes that the government attorney's interest in criminal prosecution is "not that it shall win a case, but that justice shall be done."163 As the representative of "a sovereignty whose obligation is to govern impar-

188 Singer v. United States, 380 U.S. 24, 36 (1965). Rule 24(b) of the Federal Rules of Criminal Procedure confers specified numbers of peremptory challenges upon both the defendant and the government. FED. R. CRIM. P. 24(b). The power of the Court's analogy to Rule 24(b) is questionable. The rationale for the government's right of peremptory challenge is to "permit rejection for real or imagined partiality that is less easily designated" than in the case of challenges for cause. Swain v. Alabama, 380 U.S. 202, 220 (1965). It is unlikely that the government is equally justified in erecting an earthwork against the partiality of the federal bench. Not only is it unseemly to suggest that federal judges are biased against the government, but even if one were, the prosecutor may seek his removal under 28 U.S.C. $\S 144$ (1976).

${ }^{150}$ Brief for the United States at 32, Singer v. United States, 830 U.S. 24 (1935) (quoting Berger v. United States, 295 U.S. 78, 88 (1935)).

180 Id. at 33.

101295 U.S. 78 (1935).

162 See supra text accompanying note 159.

183295 U.S. at 88. 
tially," the prosecutor has a "twofold aim . . . that guilt shall not escape or innocence suffer."164 Although the prosecutor "may strike hard blows, he is not at liberty to strike foul ones," and he must "refrain from improper methods calculated to produce a wrongful conviction as [well as] use every legitimate means to bring about a just one."165

Given that the government's interest as an adversarial litigant is more limited than the government's brief in Singer suggests, the prosecutor should not be able to insist on a jury trial once the defendant has demonstrated that the present jury from the immediate venire is a partial one. ${ }^{168}$ Under such circumstances, it would be quite ironic for the government to insist on a jury as the fact finder "most likely to produce a fair result."167 Instead, the government's insistence on a jury trial would burden the defendant with a jury of established partiality. To deprive the defendant of the most obvious solution to a partial jury-foregoing a jury trial altogether-deprives the party whose rights must be vindicated of an effective remedy and places discretion over that remedy in the hands of the adverse party whose decisions may concededly be dictated by "litigation strategy." of the criminal defendant ${ }^{168}$ - particularly one who has already demonstrated partiality-certainly outweighs the speculative possibility that a bench trial would be unfair to the prosecution. Indeed, not only may one question the propriety of giving such rein to a prosecutor's reluctance to go to trial before the federal bench, but the government's interest-" not that it shall win, but that justice be done"170 — may well be served by permitting the defendant a free election of remedies. As the Supreme Court has declared, "[w] hat were contrived as protections for the accused should not be turned into fetters."

${ }^{164} I d$.

Ies Id.

${ }^{106}$ For a discussion of the general case law on the degree of partiality that the defendant would be required to show, see supra note 42 . For an argument that the case law under Singer has demanded a uniquely high showing of prejudice, see Comment, Burden of Prejudice, supra note 24, at 990-92.

107 Singer v. United States, 380 U.S. at 36.

${ }^{168}$ Brief for the United States at 32, Singer v. United States, 380 U.S. 24 (1965).

169 See, e.g., Smith v. United States, 360 U.S. 1, 9 (1959) (traditional canon of construction calls for the strict interpretation of criminal statutes and rules in favor of defendants where substantial rights are involved); In re Murchison, 349 U.S. 133, 136 (1955) ("[O]ur system of law has always endeavored to prevent even the probability of unfairness.").

170 Berger v. United States, 295 U.S. 78, 88 (1935).

172 Adams v. United States ex rel. McCann, 317 U.S. 269, 279 (1942) (holding that defendant can waive jury trial without the assistance of counsel). This conclusion that the 


\section{Conclusion}

Singer's suggestion that Rule 23(a)'s requirement of government consent might be unconstitutional where the government's nonconsent results in the denial of the defendant's right to a fair trial has been kept alive unnecessarily by lower courts. This comment has argued that the due process guarantee of a fair trial requires a nonconsensual bench trial only where all other means of ensuring an impartial jury are inadequate. Yet, a defendant who has shcwn that an impartial jury is simply unobtainable has necessarily made out a violation of his sixth amendment right to an impartial jury. Such a showing entitles the defendant to have the prosecution dismissed. Thus, the issue raised by Singer is a false one; the fair trial guarantee as a source for a meaningful right to a nonconsensual bench trial is illusory.

Nevertheless, the significant constitutional interests impinged upon by change of venue, closure, and gag orders require that a defendant be permitted to override the government's statutory interest in a jury trial where these are the only efficacious remedies for partiality available to the defendant. Finally, an explanation of the policies supporting rule 23(a)'s requirement of government consent demonstrates that those justifications are inadequate to support the requirement once the defendant has shown jury partiality. Thus, although the rule is already subject to constitutional qualification, it should be amended to suspend the requirement of government consent entirely once the defendant has demonstrated jury partiality.

Jon Fieldman

requirement of government consent should no longer apply once the defendant has established partiality resembles that of another recent commentator on Rule 23(a). In Comment, Waiver of Jury Trials, supra note 24, at 1109, the author argues that if the defendant shows a reasonable likelihood that a jury could not provide a fair trial, then the government no longer has a presumptive right to insist on a bench trial. That argument then diverges from the present one by advocating a general balancing approach in which the court would weigh the specific reasons offered by both parties in favor of or against a bench trial. Id. at 1110 . 